\title{
XXIX. Origin of coral reefs and islands
}

\author{
James D. Dana LL.D.
}

To cite this article: James D. Dana LL.D. (1885) XXIX. Origin of coral reefs and islands, Philosophical Magazine Series 5, 20:124, 269-292, DOI: 10.1080/14786448508627754

To link to this article: http://dx.doi.org/10.1080/14786448508627754

册 Published online: 29 Apr 2009.

6 Submit your article to this journal $\pi$

Џll Article views: 3

Q View related articles $₫$ 


\section{[ 269$]$ \\ XXIX. Origin of Coral Reefs and Islands. \\ By JAMES D. DaNA, LL.D. \\ [Continued from 'p. 161.] \\ PART II.-The Objections considered.}

THE objections to the Darwinian theory may be considered in the following order :-

I. Darwin's insufficient knowledge of the facts bearing on the subject.

II. Subsidence not ordinarily a fact, because methods of producing barrier reefs and atolls have been brought forward that do not require its aid.

III. The occurrence of cases of elevation in regions of atolls and barrier-reefs inconsistent with the subsidence-theory.

IV. No ancient coral-reefs in the geological series have the great thickness attributed by the subsidence-theory to modern reefs.

V. Other methods of explanation and their supporting evidence.

The adverse remarks directed against the idea of a sinking continent in the Pacific as the initial condition in the coral-reef subsidence are outside of the present discussion for the reason stated on the first page of this paper. In the following pages the objections are first explained, under the above-mentioned heads, and then follow, in paragraphs lettered $a, b, c, \& c$. , the writer's discussions of the several points.

\section{Darwin's Insufficient Knowledge of the Facts.}

In the Address referred to in the opening page of this article, Dr. Geikie, speaking of Darwin, observes:- "It should be borne in mind that, compared with more recent explorers, he did not enjoy large opportunities for investigating coral-reefs." "He appears to have examined one atoll, the Keeling Reef, and one barrier-reef, that of Tahiti." "By a gradually widening circle of observations a series of facts has been established which were either not known, or only partially known, to Darwin."-The authors appealed to for the views that are presented as a substitute for Darwin's are Prof. Karl Semper, who has examined and described reefs of the Pelew and Philippine Islands; Dr. J. J. Rein, who has published on the physical geography of the Bermudas; Prof. Alexander Agassiz, who has written on the Florida reefs and others in that vicinity; and Mr. John Murray, of the 'Challenger' Expedition, whose investigations were made at Tahiti : all able men in science, whether more learned or

Phil. Mag. S. 5. Vol, 20. No. 124. Sept. 1885. 
not than Darwin on the special subject under discussion. The facts from "a widening circle of observations" referred to comprise the physical and biological results of deep-sea exploration. The writer is mentioned as one of the "competent observers" who had given "independent testimony" in favour of Darwin's views after "at least equal opportunities of studying the subject," and as he has, in these latter years, looked into the new facts, he has at least a claim to a hearing.

As to Darwin's knowledge, it appears to the writer that the apology offered in the above citations was not needed. In his detailed investigation of Keeling atoll (a good example of atolls, and like all the rest in its principal features) and in his examination of the Tahitian reefs, followed up by a careful study of other atolls and reefs of the ocean through the maps and descriptions of former surveying-expeditions, he had a broad basis for judgment and right conclusions. When the second edition of his work was published in 1874, many of the important facts from deep-sea exploration were already known; and later he learned of the more recent results ; and he did not recant. A letter of his, of October 2nd, 1879, published by Mr. Semper, while admitting with characteristic fairness the interest of the facts collected by the latter, expresses his continued adherence to the opinion "that the atolls and barrier reefs in the middle of the Pacific and Indian oceans indicate subsidence."

The writer, as his expositor, may be excused for adding here that his own "independent testimony" was based on observations among coral reefs and islands in the Pacific during parts of three years, 1839, 1840, 1841; that, besides working among the reefs of Tahiti, the Samoan (or Navigator) Islands, and the Feejees (at this last group staying three months), he was also at the Hawaian Islands; and in addition, he landed on and gathered facts from fifteen coralislands, seven of these in the Paumota Archipelago, one, Tongatabu, in the Friendly Group, two, Taputeuea and Apia, in the Gilbert Group, and five others near the equator east of the Gilbert Group-Swains, Fakaafo, Oatafu (Duke of York's), Hull, and Enderbury Island*. The writer may therefore be acquitted of presumption if he states his opinion freely on the various questions that have been brought into the discussion by other investigators. Sympathizing fully with the sentiment expressed in the words, "The example of Darwin's own candour and over-mastering love of truth remains to assure

* These five islands are on the map of the Central Pacific accompanyt ing Part I. of this paper. Hull's Island is "Sydney" of the writer's Expedition Report. 
us that no one would have welcomed fresh discoveries more heartily than he, even should they lead to the setting aside of his work:" and knowing that we are all for the truth and right theory, he has reason to believe that those who have been led to object to Darwin's conclusions will be pleased to have their objections reviewed by one who has a personal knowledge of many of the facts.

\section{Subsidence not ordinarily a Fact, because Methods of Origin have been brought forward that do not require its aid.}

It is urged that, while subsidence may have happened in several cases, it is not at all necessary to the making of barrier-reefs and atolls ; that "subsidence has been invoked because no other solution of the problem seemed admissible;" that the "solution" by subsidence "is only an inference resting on no positive proofs"*.

a. Darwin's usual methods were not such as these words imply, and we think that he was true to those methods in his treatment of coral-island facts. Darwin can hardly be said to have "invoked" subsidence. Subsidence forced itself upon his attention. He saw evidence that it was a fact, and the theory came ready-made to him. The proof of subsidence from the relations in form, structure, and history between atolls and the large barrier-islands, like the Gambier Group, Raiatea, Bolabola, and Hogoleu, scarcely admitted, he says, of a doubt; and other facts were all in harmony with it. This, his chief argument, with the enforcing evidence in my Report (see $\S \S$ 4 and 10 of Part I. of this paper) is not set aside and not mentioned in the Address from which the above sentences are cited.

b. Darwin observes that "from the nature of things it is scarcely possible to find direct proof of the subsidence," recognizing the fact that subsidence, unlike elevation, puts direct testimony out of sight. But still it has left evidence which he perceived and thought convincing; and this stands, whatever virtue there may be in other explanations.

Moreover, we have now direct testimony for subsidence from the facts brought forward (for another purpose) by Mr. Murray, as is set forth further on.

III. The Occurrence of cases of Eleration in Regions of Atolls and Barrier-Reefs.

The fact that elevated reefs and other evidences of eleva* Address, page 24.

$\mathrm{U} 2$ 
tion occur at the Pelews, a region of wide barrier-reefs and atolls, has been presented by Prof. Karl Semper*, after a study of those jslands, as an objection to the theory of subsidence; for we have thereby (in the words of the Address) "a cumbrous and entirely hypothetical series of upward and downward movements." Prof. Semper reports the existence of reefs raised 200 to 250 feet above the sea-level in the soutbern third of the larger of the islands, while the other two thirds exhibit evidence of but little, if any, elevation.

$a$. Such facts are of the same general character with those of other elevated reefs and atolls discussed in $\$ \S 12,13,16^{\circ}$ of Part I. and the same explanation covers them. The Pelew region is one of comparatively modern volcanic rocks, and this renders local displacements a probability.

b. The occurrence of great numbers of large and small masses of coral-rock, in some places crowded together, apon the western or leeward reef of the several Pelew Islands, and of none on the eastern reef, is mentioned as evidence against subsidence and in favour of some elevation; because, Professor Semper says, the strongest wind-waves on the western side are too feeble to break off and leave on the reef such large masses, some of them (as his words imply rather than distinctly state) ten feet thick.

But the difficulty does not exist in fact; for earthquakes may have made the waves. The region just west of the Pelews is one of the grandest areas of active volcanoes on the globe. It embraces the Philippine Islands, Krakatoa and other volcanic islands of the Sooloo sea, Celebes, \&c. The agents that could do the work were there in force. To the eastward, in contrast, lie the harmless islands of the Caroline Archipelago, mostly atolls, serving, perhaps, as a breakwater to the Pelews.

The small elevation referred to is therefore not proved by the evidence adduced; and yet it may be a fact without affecting the theory of Darwin, as I have fully illustrated $\dagger$.

It is important to have in mind that the coral-reef era probably covered the whole of the Quaternary and perhaps the Pliocene Tertiary also; and hence the local elevations that

* First in 1868, Zeitschr. Wrissensch. Zool. xiii. p. 558; additions in Die Philippinen und ihre Bewohner, Würzburg, 1869; and still later in his 'Animal Life,' published in Appleton's International Scientific Series in 1381.

$+\mathrm{Mr}$. Semper's objection to the theory of subsidence based on the coexistence of all kinds of reefs in the Pelews-atoll, fringing, and barrierwith no reefs about one island, and from the relative steepness of the submarine slopes on the east and west reefs of an island, have been sufficiently met in l'art I. 
have taken place in the ocean were not crowded events of a short period.

Moreover, these local elevations in coral-seas are spread over an area of 25,000,000 square miles. As an example of the long distances, the Paumotu Archipelago, consisting of more than eighty atolls and two barrier-islands, and covering about 450,000 square miles, contains only three or four atolls that are over twelve feet high ; and of these, Metia is 250 foet in height, Elizabeth 80 feet, Dean's, probably where highest, 15 or 20 feet. Metia is one of the westernmost, near $148^{\circ} 13^{\prime} \mathrm{W}$. and $15^{\circ} 50^{\prime} \mathrm{S}$.; Dean's is 60 miles to the northnorth-east of Metia, and Elizabeth is far to the south-east, in $128^{\circ} \mathrm{W}$. and $25^{\circ} 50^{\prime} \mathrm{S}$., or nearly 1450 miles distant from Metia. Locate these points on a continent, and Pacific distances and the length of Pacific chains of atolls will be appreciated.

IV. No Ancient Coral-reefs have the Thickness attributed by the Subsidence-Theory to Modern Reefs.

An argument against the subsidence-theory is based by Prof. J. J. Rein * on the alleged fact that the thickness attributed to modern reefs is far beyond that of any such reefs in earlier time; that is, the thickness is unprecedented. The argument decides nothing. The question is one of geological fact, not to be settled by a precedent. Whether, then, there are precedents or not it is not necessary to consider.

Besides this, it implies a distinction between coral-made and shell-made rocks which does not exist. The coral-reef rock is largely made of shells, and the process of formation for a limestone of shallow-sea origin is essentially the same whether shells or corals are predominant or the sole material. No thick formation of any kind of rock was ever made, or could be made, by shore or shallow-sea operations without a slowly continued subsidence or a corresponding change of water-level.

\section{Other Methods of Explanation, and their Supporting Evidence.}

A. Mr. John Murray, one of the able naturalists of the 'Challenger' expedition, reports the following important results

* Dr. Rein's first memoir on Bermuda appeared in the Senckenberg Ber. naturforsch. Gesellschaft, 1869-70, p. 857, and the later in the Verhandlung des $I$. deutsch. Geographentages, 1881, Berlin, 1882. The above argument is from the latter paper, and is given here frum the citation by Dr. Geikie, the publication not being accessible to the writer. 
from soundings off northern Tahiti, made under his supervision and that of the surveying officers *.

Along a line outward from the edge of the barrier-reef there were found :-(1) for about 250 yards, a shallow region covered partly with growing corals, which deepened seaward to 40 fathoms; (2) for 100 yards, between the depths of 40 and 100 fathoms, a steeply but irregularly sloping surface, which commenced with a precipice of $75^{\circ}$ and had a mean angle exceeding $45^{\circ} \dagger$; then (3) for 150 yards a sloping bottom $30^{\circ}$ in angle; (4) then a continuation of this sloping surface, diminishing in a mile to $6^{\circ}$, at which distance out the depth found was 590 fathoms (3540 feet). Over the area (2), or the 100 yards between 40 and 100 fathoms, the bottom was proved to be made of large coral-masses, some of them " 20 to 30 feet in length," along with finer débris ; ontside of this, of sand to where the slope was reduced to $6^{\circ}$; and then of mud, composed " of volcanic and coral-sand, pteropods, pelagic and other foraminifers, coccoliths, \&c."

These observations have great significance. They show (1) that the feeble currents off this part of Tahiti carry little of the coral débris in that direction beyond a mile outside of the growing reef ; (2) that a region of large masses of coral-rock and finer material occurs at depths between 240 and 600 feet; (3) that, a mile out, the bottom has the slope nearly of the adjoining land, and in this part is covered with the remains of pelagic life.

From the second of these facts-the great accumulation of coral-blocks below a level of 240 feet-Mr. Murray draws the conclusion that, in the making of fringing, barrier, and atoll reefs, the widening goes forward $(a)$ by making first upon the submarine slopes outside of the growing reef a pile of coral-débris up to the lower limit of living reef-corals; and then (b) by building outward upon this accumulation as a base.

He also announces, after speaking of other causes influencing the growth of corals, the more general conclusion that "it is not necessary to call in subsidence to explain any of the characteristic features of barrier-reefs and atolls;" and concludes that his views "do away with the great and general subsidences " appealed to by Darwin.

$a$. The widening-process, in the first conclusion, had previously been a part of the Darwinian theory; for, as

* Proc. Edinburgh Roy. Soc., Session 1879-80, p. 505.

$\dagger$ Dr. Geikie gives in his paper a section of the soundings, " on a true scale, vertical and horizontal," and in it the upper steepest part of this 100 yards has a slope of about $75^{\circ}$. 
stated in $\$ 10$ (Part I.), a fringing reef, where no subsidence is going on, widens above and steepens its seaward-slope, and it could do this only by the process described : that is, by building out upon a base of débris, or, more correctly, upon true coral-reef rock made by the gradual consolidation of the débris *.

$b$. The broader conclusion Mr. Murray does not sustain by a mention of special facts from the soundings, tending directly to meet the question of change of level, but by attempting to show that through the eroding action of currents and other means (as had been argued by Prof. Semper), in connection with the process already explained, reefs of all kinds can be made from submarine banks without aid from subsidence.

In this place I confine myself to the question as to the fact of subsidence. The only direct argument presented against subsidence is contained in the statement, that the very broad shore-plain of Tahiti shows that " the island has not in recent times undergone subsidence," and may indicate a slight elevation ; and in this he sustains the earlier statement of my report, which says (p. 293) that the broad shore-plain of Tahiti probably overlies in some parts the fringing reef; and (p. 300) the shore-plain, if built upon reefs, as I was assured, may afford proof of a rise of one or two feet." But this admission, as I have explained for other cases of local elevation, is in no way opposed to the theory of subsidence.

$c$. The kind of submarine slopes to be looked for off reefs is illustrated by the soundings, as Dr. Geikie indicates. But it is interesting to note that the facts, while very important, sustain instead of correcting those announced by earlier observers. Beechey and Darwin make the mean slope about $45^{\circ}$, and my report says $40^{\circ}$ to $50^{\circ}$. I have assumed for the slope of the bottom outside of the reef-limit the same angle as for the surface-slope of the island just above the water-level: $5^{\circ}$ to $8^{\circ}$ off Tahiti, of which $5^{\circ}$ is accepted as most correct, and $3^{\circ}$ to $5^{\circ}$ off Upoln $\dagger$; and the assumption as regards Tahiti is sustained by the 'Challenger' soundings. My Report states (from the Expedition surveys) that off Upolu the bottom "loses more and more in the proportion of coral-sand till we finally reach a bottom of earth," and introduces this as an argument against the indefinite drifting of coral-sands into the deep ocean $\ddagger$; and this argument the Tahiti soundings sustain.

With reference to the occurrence off some shores of precipi-

* My Expedition Geological Report, pp. 131, 132, where figures are given illustrating the effect of widening.

+ Page 47.

$\ddagger$ Page 154 . 
tous submarine slopes, the 'Challenger' soundings give definite facts as to one case. They leave undisturbed the previously reported cases of like steepness at greater depths : for example, the sounding of Captain Fitzroy at Keeling atoll (while Darwin was there), 2200 yards from the breakers, in which no bottom was found at a depth of 1200 fathoms, but the line was partly cut at a depth between 500 and 600 fathoms ; the sounding by the Wilkes Expedition off Clermont Tonnere (Paumotu Archipelago), where the lead, brought up an instant at 350 fathoms and then dropped off again, descended to 600 fathoms without reaching bottom, and came up bruised, with small pieces of white and red coral attached; a sounding by the same Expedition, a " cable's length" from Ahii, in which the lead struck a ledge of rock at 150 fathoms and brought up finally at 300 fathoms *. All the older soundings need to be repeated; but there must be enough truth in those quoted to warrant the remark that the force of Darwin's argument for subsidence from the steepness of the submarine slopes about atolls is not weakened by the 'Challenger' results.

$d$. But the chief interest of the "Challenger' soundings consists in their affording "direct" proof, "positive" proof, of much subsidence; a kind of proof that subsidence sinks out of sight, and which soundings may yet make available in many similar cases.

That belt of coarse débris-including "masses 20 to 30 feet" long-was found over the steeply sloping bottom at depths between 240 and 600 feet. These depths are far below the limit of forcible wave-action. They are depths where the waters, however disturbed above by storms, have no rending and lifting power, even when the bottom is gradually shelving; depths, in this special case, against a slope which for 100 yards is $75^{\circ}$ in its upper part, and in no part under $45^{\circ}$, the vertical fall being 360 feet in the 100 yards. Strokes against the reef-rock thus submerged, and under such conditions, would be extremely feeble. Waves advancing up a coast, whether storm-driven waves or earthquake waves, do little rock-rending below the depth to which they can bare the bottom for a broadside plunge against the obstacle before them, although the velocity gives them transporting power to a greater depth. It is the throw of an immense mass of water against the front, with the velocity increased by the tidal flow over a shelving bottom, - the rate sometimes amounting, according to Stevenson, to 36 miles an hour or 52.8 feet a second,-together with the buoyant action of the water, that produces the great effects. 
A vertical surface below the sea-level of 20 feet made bare for the broadside stroke is probably very rarely exceeded even in the case of earthquake-waves ; and with storm-waves, or recorded earthquake-waves, the displacement of the water at a depth of 240 feet would be at the most only a few inches. I saw on atoll reef's no upthrown masses of coral-rock over ten feet in thickness and twenty feet in length or breadth. It is therefore plainly impossible that such a belt of débris should have been made at its present level, or even at a depth of 20 feet; and hence the débris affords positive proof of a large subsidence during some part of the reef-making era.

The existence of the belt of débris may be explained as follows :-If the reef now at a depth of 240 feet were at the sea-level as the sea-level reef, and subsidence were not in progress for a period, the very steep front of the reef now just below the 240-foot level might have resulted from the widening that would have gone forward. And under such conditions, the action of the occasional extraordinary waves might have torn off masses from the front which would have tumbled down the steeply sloping surface until the belt of débris had been formed. Then, with a renewal of the slow subsidence, the thickening of the reef would have been resumed and gone on to its final limit, and the rendings of the great waves found lodgment at higher levels. The masses now on atoll reefs must be from comparatively recent upthrows.

This direct evidence of subsidence from Tahiti renders it reasonable to make subsidence in atoll-making a general truth. It is nevertheless desirable that facts of the kind should be multiplied. The abrupt descent in the submarine slopes of reefs detected by Fitzroy at a depth below 3000 feet, and those reported by the Wilkes Expedition at depths of 2100 and 900 feet, seem to indicate a similar rest at the sealevel, and consequent reef-widening in the course of a progressing subsidence; and proof of this may yet be found in belts of coarse coral-rock débris at the foot of the precipices. Such a period of rest would lead to the forming of submarine precipices in different regions contemporaneously at different depths according to the rate of subsidence of the part of the subsiding area.

B. From facts observed about the Florida reefs, Lieutenant E. B. Hunt, U.S.N., announced, in $1863 *$, the conclusion that these reefs had received their westward elongation * Silliman's American Journal [2] xxxr.p. 197. 
through the westward "sweep" of an eddy current to the Gulf Stream. The subject, nearly twenty years afterwards, was more thoroughly investigated by Mr. Alexander Agassiz, and the same conclusion reached *. Mr. Agassiz made also another importantobservation-that this current is an abundant carrier of marine life for the feeding of the coral animals, and so accelerates the coral-growth and accumulation in its direction. Combining with these effects others hereafter considered, Mr. Agassiz expresses, like Mr. Murray and Mr. Semper, the further conclusion, that all kinds of reefs-atoll, fringing, and barrier-may be made without aid from subsidence.

$a$. The facts presented by Lieutenant Hunt, and more fully by Mr. Agassiz, with regard to the effects of the eddy current of the Gulf-Stream, show that coral-reefs may be elongated, and also that inner channels may be made, by the drifting of coral-sands. But the action with coral-sands is essentially the same as with other sands ; and illustrations of this drifting process occur along the whole eastern coast of North America from Florida to Long Island. We there learn that drift-made beaches run in long lines between broad channels or sounds and the ocean; that they have nearly the uniform direction of the drift of the waters, with some irregularities introduced by the forms of the coast and the outflow of the inner waters, which are tidal and fluvial and have much strength during ebb tide. The easy consolidation of coralsands puts in a peculiar feature, but not one that affects the direction of drift accumulation.

$b$. The great barrier-reef off eastern Australia, a thousand miles long, has some correspondence in position to the sandreefs off eastern North America. But it is full of irregularities of direction and of interruptions, and follows in no part an even line. In the southern half, it extends out 150 miles from the coast and includes a large atoll-formed reef; in the northern half, the barrier, while varying much in course, is hardly over 30 miles from the land. There is very little in its

* On the Tortugas and Florida Reefs, by A. Agassiz, Trans. Amer. Acad. xi. 1883.

Professor Louis Agassiz's account of the Florida reefs was published in the U.S. Coast Survey Reports of 1851 and 1866 , and reproduced in vol. vii. of the Memoirs of the Museum of Comparative Zoology. It gives an excellent description of the Florida reefs, and of the action of boring animals and other injurious agents on corals, and reaches the conclusion that the reef has been raised to its present level and thickness by wave and current action, without the aid of elevation or subsidence. The argument is based on such observations as could be made over the surface of the reefs and the adjoining sea-bottom, and bears on the question of the necessity of subsidence, and not on the fact of subsidence. 
form to suggest similarity of origin to the drift-made barriers of sand.

c. In the Pacific Ocean, the trends of many of the coralisland groups and of the single islands do not correspond with the direction of the oceanic currents, or with any eddy currents except such as are local and are determined by themselves.

Near longitude $180^{\circ}$, as the map of the Central Pacific (see Part I.) illustrates, the equator is crossed by the long Gilbert (or Kingsmill) group, at an angle with the meridian of $25^{\circ}$ to $30^{\circ}$, and not in the direction of the Pacific current, which is approximately equatorial. This obliquely crossing chain of atolls is continued northward in the Ratack and Ralick Groups (or the Marshall Islands), making in all a chain over 1200 miles long ; and, adding the concordant Ellice Islands on the south, and extending the Ratack line to Gaspar Rico, its northern outlier, the chain is nearly 2000 miles long. Nothing in the direction of the long range, excepting local shapings of some of the points about the atolls, can be attributed to the Pacific currents. Moreover, the diversified forms of the atolls have no sufficient explanation in the drift process.

d. Further, drifting by currents may make beaches and inner channels whether subsidence is going on in the region or not, and are not evidence forl or against| either a movement downward or upward. Sandy Hook, the long sandy point off the southern cape of New York harbour, has been undergoing (as the U. S. Coast Survey has shown) an increase in length, or rather variations in length, through the drifting of sands by an outside and an inside current; and this is no evidence that Professor G. H. Cook is wrong in his conclusion that the New Jersey coast is slowly subsiding.

$e$. But even in this region of Florida we have strong evidence of a great subsidence during the coral-reef era, and all the subsidence that the Darwinian theory demands.

In a very valuable paper by Mr. Agassiz, published in 1879 in the Bulletin of the Museum of Comparative Zoology *, the author points out that the South American continent, in comparatively recent geological times, had connection with the West-India Islands through two lines : (1) one along a belt from the Mosquito Coast to Jamaica, Porto Rico, and Cuba; and (2) the other through Trinidad to Anguilla, of the Windward Islands. He sustains the conclusion by a review of the soundings made by the steamer 'Blake,' under the command of

* An abstract of the paper is contained in Silliman's American Journal [3] x viii. p. 230 (1880). 
J. R. Bartlett, U.S.N., and a consideration of the facts connected with the distribution of marine and terrestrial species. As the soundings show, the former of the two connections requires for completeness an elevation of the region amounting to 4060 feet over the part south of Jamaica, 4830 feet between Jamaica and Hayti, and 5240 feet between Hayti and Cuba. The other line of connection requires an elevation of 3450 feet. An open channel, as be observes, would thus be left between Anguilla and the Virgin Islands, where there is now a depth of 6400 feet. The close relations in the existing fauna of the Gulf to that of the Pacific waters prove that it continued to be a salt-water gulf through the era of elevation.

$M_{r}$. Agassiz infers that the connection of the West-India Islands with South America existed before the Quaternary era. But there are other facts which seem to prove that it was continued into, or at least was a fact in, the Quaternary.

The opinion as to a connection of the Windward Islands with South America in the Quaternary was presented by Prof. E. D. Cope in 1868, and earlier, as he states, by Pomel, on the ground of the discovery in the caves of Anguilla of a species of gigantic Rodent related to the Chinchilla, as large as the Virginia Deer, and nearly equalling the Quaternary Castoroides of Ohio *. Further, De Castro, as cited by Dr.J. Leidy in his 'Mammalian Fauna of Dakota and Nebraska,' 1869, announced, in 1865, a gigantic Sloth of the "Quaternary," from Cuba, which he referred to the genus Megalonyx, and Dr. Leidy named Megalocnus rodens, proving a Quaternary connection between the continent and Cuba.

The fact of an elevated condition of the region sufficient to make Cuba and Anguilla part of the continent during the earlier Quaternary, if not in the Pliocene also, is thus made quite certain. This is fully recognized by Wallace $\dagger$. Such a condition could hardly have existed without a large elevation also of Florida, though probably not, as Mr. Agassiz holds, to the full amount of the depression between it and Cuba (nearly 3000 feet), because Cuba is most closely related in fauna to South America. The subsidence which brought the region to

* Proc. Philad. Acad. Nat. Sci. 1868, p. 313, and Proc. Philad. Amer. Phil. Soc. 1869, p. 183; also 'Smithsonian Contributions to Knowledge; 30 pp., 4to, with 5 plates, Washington, 1883 . The last paper (prepared in 1878) contains descriptions of the following species from the Anguilla one-cave :-Amblyrhiza inundata, Cope (the large Rodent announced in 869), A. quadrans, Cope, A. latidens, Cope, an Artiodactyl apparently of ine Bovide and a little smaller than Ovis aries. With them was obtained in implement ("a spoon-shaped scraper or chisel ") made of the lip of the arge Strombus gigas.

† Geograph, Distrib. of Animals, ii. pp. 60, 78 . 
the present level was consequently within the coral-reef period. It is hence hardly to be doubted that the making of the Florida, Bahama, and other West India coral-reefs was going on during the progress of a great subsidence. None of the facts mentioned by observers are opposed to this view.

It is of interest to note here that on Cuba and Jamaica there are elevated coral-reefs, the highest on Cuba 1000 feet above the sea, according to Mr. Agassiz, and probably at one point 2000, according to Mr. W. O. Crosby's observations *, and on Jamaica 2000 feet, according to Mr. Sawkins; indicating that there have been upward movements subsequent to the downward. Mr. Crosby argues that the great thickness of the now elevated reefs could have been produced only "during a progressing subsidence;" so that "we have apparently no recourse but to accept Darwin's theory."

C. It has been urged by Mr. Semper, Dr. J. J. Rein, Mr. A. Agassiz, Mr. Murray, Dr. Geikie, and others, that since the growing calcareous deposits of the sea-bottom are slowly rising toward the surface by successive accumulations of the shells and other débris of marine species, they may have been built up locally in various regions of the deep seas (as they actually are now about some islands) until they were near enough to the surface to become next a plantation of corals; and that in this way atolls became common within the area of the tropical oceans. The method is regarded as setting aside subsidence.

$a$. The advocates of this hypothesis have not pointed to such a mound now approaching the ocean's surface on the western border of the Gulf-Stream, where the depth over the remarkably luxuriant region is least; and none over any part of the tropical Pacific. It is suggested that the Chagos Bank may be one example; but it is not known to be so. Professor Semper states that he found evidence of pelagic life, instead of modern corals, in the lower part of the elevated reefs of the Pelews. Dr. Geikie cites from letters by Dr. Guppy in 'Nature' of Nov. 29, Dec. 6, 1883, and Jan. 12, 1884, the fact that in elevated reefs on the Salomon Islands, 100 and 1200 feet high, the coral-rock forms a comparatively thin layer over impure earthy limestone abounding in foraminifers and other pelagic organisms such as Pteropods. Such obser-

* Proc. Boston Soc. Nat. Hist. xxii. p. 124, (1882), and in abstract in Silliman's American Joumal, xxri. p. 148 (1883). 
vations have great interest, but they only prove that, in coralreef seas, corals will grow over any basis of rock that may offer where the water is right in depth, and do not nullify any of the evidences of subsidence. This point should be kept before the mind in all future study of coral-reef regions. Borings in coral-islands, as recommended on a former page, are the true means of investigating it.

$b$. The old hypothesis that atolls may have been built upon the summits of submerged mountain-peaks, or volcanic cones at the right distance under water for growing reef-corals, or, if not at the right level, brought up to it by other organic depositions, or down to it by abrasion, is urged by Mr. Murray.

This writer observes that " the soundings of the "Tuscarora" and 'Challenger' have made known numerous submarine elevations; mountains rising from the general level of the ocean's bed at a depth of 2500 or 3000 fathoms, up to within a few hundred fathoms of the surface." But "a few hundred fathoms," if we make few equal 2, means 1200 feet or more, which leaves a long interval yet unfilled *.

It is also urged that some of the "emerged volcanic mountains situated in the ocean-basins" may have been wholly swept away and left with a few fathoms of water above them. But this is claiming more from the agents of erosion than they could possibly have accomplished, as the existence of an atoll in the ocean and the examples on coasts of wave and tidal action prove.

D. To give completeness to the hypothesis which makes barrier and atoll islands out of submarine banks (whether these banks have a basis of volcanic or other rocks, or of calcareous accumulations), it is necessary to show that the waters of the waves and currents can make barrier islands and atolls out of such banks without subsidence; and explanations to this effect have been given.

It is urged, in agreement with Darwin, that the outer por-

* The actual depths over the elerations in the 'Tuscarora' section between the Hawaian Islands and Japan, numbering them from east to west, are as follows :-1, 11,500 feet; 2,7500 feet; 3, 8400 feet; 4, 12,000 feet; 5,9000 feet (this seven miles west of Marcus Island); 6, 9600 feet. Whether ridges or peaks the facts do not decide; probably the former. No. 1 has a base of 185 miles, with the mean eastward slope 40 feet per mile $(=1: 132)$, and the westward 128 feet per mile. No. 2 has a breadth of 396 miles, with the mean eastern slope mostly 37 feet per mile, but 51 feet toward the top, and the westward, 55 feet per mile $(=1: 96)$. No. 3 was the narrowest and steepest, it being about 100 miles broad at base, and having the mean eastern slope 192 feet per mile and the menn western 200 feet. 
tions of reefs increase faster than the inner, owing to the purer water about them and the more abundant life for food ; that the inner parts are not only at a disadvantage in these respects, but suffer also from coral débris thrown over them. They add to these causes of unequal growth mentioned by Darwin, the solvent and abrading action of the waters.

It is hence concluded that, under these conditions, the simple bank of growing corals may have a depression made at the centre, which, as the process continues, will become a lagoon basin, and the reef thereby an atoll with a shallow lagoon; that the atoll, so begun, may continue to enlarge through the external widening of the reef and the further action of current-abrasion and solution within : or, in the case of fringing reefs, that the change may go on until the reef has become a barrier-reef, with an inner channel and inner reefs. It is admitted that subsidence may possibly have helped in the case of the deepest lagoons.

Dr. Geikie expresses his opinion on the subject thus :- "As the atoll increases in size the lagoon becomes proportionally larger, partly from its waters being less supplied with pelagic food, and therefore less favourable to the growth of the more massive kinds of corals, partly from the injurious effects of calcareous sediment upon coral-growth there, and partly also from the solvent action of the carbonic acid of the sea-water upon the dead coral."

Mr. Semper gives examples of the effects of currents at the Pelew Islands, stating that, by striking against or flowing by the living corals, they make the reef grow with steeper sides and determine its direction, and urging that abrasion and solution have made, not only the deep lagoon-like channels, but the deeper channels between the islands. He holds that in Kriangle, which he describes as a true atoll with no channel leading into the lagoon from the sea, the lagoon may have been "the result of the action of currents on the porous soil during a period of slow upheaval*. He says, further, that the large channel in the main island of the group "forty fathoms deep and many miles wide," "finds an easy explanation on the assumption of an upheaval ;" it became "wider in proportion as the enclosed island, consisting of soft stone [tufa], was gradually eaten away; and during slow upheaval it would continue to grow deeper in proportion as the old porous portions of the reef and the rock in which it was forming were more and more worn down by the combined action of boring animals and plants, and of the currents

$$
\text { * 'Animal Life,' pp. 269, } 2 \text { ro. }
$$


produced by the tides and by rain." Mr. Semper refers to the dead depressed tops of some masses of Porites near tidelevel, as the effects of the deposit of sediment over the top of the living coral, and of erosion by the waves and exposure to rains while the sides continued to grow ; and the fact is made an example on a very small scale of atoll-making. Other examples of the action of currents, sediments, boring species, and the solvent action of carbonic acid in the waters are mentioned by Mr. Agassiz, in his excellent account of the "Tortugas and Florida reefs."

a. The theory, if satisfactory, accounts not only for the origin of an atoll, but for the origin of atolls of all sizes, shapes, and conditions, and for great numbers of them in archipelagos and chains; not only for channels through fringing reefs, like those that abrasion in other cases makes, but for all the irregular outlines of barriers, for the great barriers reaching far away from any land, and for the positions and indented coasts of the small included lands. Is it a sufficient explanation of the facts?

$b$. The currents that influence the structure of reefs are : (1) the general movement or drift of the ocean, in some parts varying with seasonal variations in the winds; (2) the currents connected with wave-action and the inflowing tide over a shelving bottom; (3) the currents during the ebb, flowing out of channels ; together with (4) counter-currents. Each region must have its special study in order to mark out all the local effects that currents occasion. Such effects are produced whether a secular subsidence is in progress or not, and hence a particular review of the subject in this place is unnecessary.

The shaping of the outside of the reef and the determination of the width and level surface of the shore platform are due chiefly to the tidal flow and the accompanying action of windwaves, as explained in $\S 17$ of Part I.*

* Since the first part of my paper was published I have obserred in an article by Mr. A. R. Hunt, in the Scientific Proceedings of the Royal Dublin Society, iv.p. 254, January 1885, the remark, referring to a statement of the above fact in my" Manual of Geology' that the "statement, though strictly in accordance with Mr. Russel's theory, has, so far as I can ascertain, no foundation in fact." The statement, as I have said (and as I illustrate in $m y$ 'Geology'), was but the statement of a fact observed by me first in 1839 on the coasts of Australia and New Zealand, without a thought of any theory; and part of the explanation is overlooked by $\mathrm{Mr}$. Hunt. I observed that the first waters of the incoming tide swelled over the sandstone platform (which was a hundred yards or more wide off the Port-Jackson Heads), and became thus a protector of the sandstone platform from breaker strokes; and that the lower part of the sandstone bluff to a height a little above high tide was bollowed out by the strokes 
The current that accompanies the ebb is locally the strongest. Owing to the great width of many barrier-reefs and of the channels and harbours within them, the tide flows in over a wide region. At the turn in the tide the waters escape at first freely over the same wide region; but, with a tide of but two or three feet, there is but little fall before the reefwhich lies at low-tide level and a little above it-retards it by friction; and thus escape by the open entrances is increased in amount and in rate of flow. The facts are the same in atolls where the lagoons have entrances*.

of the breakers. A similar erosion near high-tide level of the great coral masses standing on the coral-rock platform of atolls I also observed while among the Paumotu Islands. Prof. A. E. Verrill informs me that he has seen examples of the same action on a grand scale about the island of Anticosti in the Gulf of St. Lawrence. The observations do not appear to me to be at variance with the principles laid down in Mr. Hunt's valuable paper; they require only his recognition of a tidal effect which he does not fully consider, and which British seas cannot illustrate.

To produce a platform, (1) the rock-material exposed to the flow of the tide and the breakers must be firm enough to resist wear during the early part of the flow, and, at the same time, soft enough to allow the striking breakers to cut into the base of the bluff, or shear off the projecting ledge; and (2) the region must not be one of very high tides or stormy seas, for, in such regions of forceful waves and tides, the movements are too often of the destructive kind through the whole continuance of the flow leaving no chance for the protection a platform needs. Loose sand-deposits are too soft; they are worn off below the sea-level and changed in surface by storms; but some firmer kinds may make a lowtide flat in a bay where the tides are small. Coral-reef rock, the material of the atoll platform, has the hardness and solubility in carbonated seawater of ordinary limestone. The rock of the Port-Jackson Heads is a friable sandstone. At the Bay of Islands, New Zealand, the platforms occur in an argillaceous rock, which becomes soft and earthy above by weathering, but is unaltered and firm below because kept wet (loc. cit. p. 442). At the Paumotus the tides are two to three feet high, and the platform usually 100 yards or more wide; at the Phoenix Group the tides are five to six feet high and the platform mostly 50 to 70 yards wide; at the Port-Jackson Heads, the ordinary tides are six feet high and the platform 50 to 150 yards wide; at the Bay of Islands (in the sheltered waters of the bay), the tides are eight feet high and the platform is under 30 yards wide.

* The currents of the tropical Pacific Ocean are of very unequal rate in its different parts, and very feeble in the Paumotu Archipelago and the Tahitian and Samoan regions. Capt. Wilkes reports that in the cruise of the Expedition through the Paumotu Archipelago to Tahiti, a distance of a thousand miles, during a month from August 13 to September 13, 1839, the drift of the vessels was only 17 miles; and that during fourteen days in the first half of October, between Tahiti and Upolu of the Samoan group, nearly 1800 miles, the drift was only 43 miles.

The 'Challenger,' on her route from the Hawaian Islands to Tahiti, found, between the parallel of $10^{\circ} \mathrm{S}$. and Tahiti, " the general tendency of the current westerly, but its velocity variable " between the parallels of $10^{\circ} \mathrm{S}$.

Plil. Mag. S. 5. Vol. 20. No. 124. Sept. 1885 . 
c. Examples of massive corals having the top flat or depressed and lifeless, while the sides are living, are common in coral-reef regions, wherever such corals are exposed to the deposition of sediment, and where they have grown up to the surface so that the top is bare above low tide. A disk of Porites, having the top flat and the sides raised (owing to gruwth), so as to give it an elevated border, is figured on plate lv. of my Report on Zoophytes. Many such were found in the impure waters of a shore-reef at the Feejees. At Tongatabu one flat-topped mass of Porites was twenty-five feet in diameter; and both there and in the Feejees, others of Astræids and Meandrinas measured twelve to fifteen feet in diameter.

Over the dead surfaces, as Mr. Semper observes, the coral may be eroded by the solvent action of the waters, and especially where depressions occur to receive any deposits, and boring animals may riddle the coral with holes or tubes. But generally the erosion is superficial ; the large masses referred to showed little of it. Such dead surfaces in corals are generally protected by a covering of nullipores and other incrusting forms of life, and the crusts usually spread over the surfaces pari passu with the dying of the polyps.

d. Every stream, says Mr. Semper (when explaining, as cited on a preceding page, the origin of the deep channel of the large Pelew island, whose depth is " 35 to 45 fathoms"), " has a natural tendency to deepen its bed." But there is a limit to this aetion. The eroding or deepening power of a stream

and $6^{\circ} \mathrm{N}$., the direction was westerly with "the average velocity 35 miles per day, the range 17 to 70 miles per day," the maximum occurring along the parallel of $2^{\circ} \mathrm{N}$. Further west, about the Phœnix group, the equatorial current as described by Mr. Hague (loc. cit. p. 237), has "a general direction of west-south-west and a velocity sometimes exceeding two niles per hour." At times it changes suddenly and flows as rapidly to the eastward. The drifting of the sands about Baker's Island (in latitude $0^{\circ} 13^{\prime} \mathrm{N}$., longitude $176^{\circ} 22^{\prime} \mathrm{E}$.) has much interest in connection with this subject of current-action, and the facts are here cited from $\mathrm{Mr}$. Hague's paper. The west side of the little island $\left(1 \times \frac{2}{3} \mathrm{~m}\right.$. in area) trends north-east, and the southern east-by-north, and at the junction a spit of sand extends out. During the summer the ocean swell, like the wind, comes from the south-east, and strikes the south side; and consequently the beach sands of that side are drifted around the point and heaped up on the western or leeward side, forming a plateau along the beach two or three hundred feet wide, and eight or ten feet deep over the shore-platform. With Oetober and November comes the winter swell from the north-east, which sweeps along the western shore; and in two or three months the sands of the platean are all drifted back to the south side, which is then the protected side, extending the beach of that side two or three hundred feet. This lasts until February or March, when the operation is repeated. 
through abrasion and transportation is null or nearly so below the level of its outlet. A basin or channel 45 fathoms (270 feet) deep, with an outlet of much less depth, could not be deepened by such means or protect itself from shallowing. The depth of the outlets is not stated, except that they are said to be ship-channels. Moreover, with a tufa bottom, solution could not contribute to the removal, since carbonated waters, although decomposing the tufa, dissolve very little of its ingredients. An elevation in progress would result in making of the channel a closed lake, and finally dry land.

For the same reason, the small atoll, Kriangle, having, as described, a closed lagoon, could have no deepening of the lagoon from abrasion by tidal currents or wave-action during the progress of an elevation. And if a lagoon have an outlet, the rapid current of the ebb would be confined to the narrow passage-way and a portion of the bottom near it; through the larger part of the lagoon, as in any other lake, the waters would have scarcely perceptible motion, and therefore slight energy for any kind of work. Hence a lagoon would lose very little by this means, and shallowing would go on unless there were great loss through the solvent action of the waters. An elevation would only hurry the shallowing and end in emptying the lagoon.

e. Erosion through solvent action is promoted by the presence in the waters both of carbonic acid and organic acids. The material within reach of the tides or waves exposed to this action is dead corals and shells, or their débris, and bare coral rocks, occurring over-(1) the outer region of living corals and for a mile or so outside; ( 2 ) the shore plattorm and the reef, bare at low tide, on which there is comparatively little living coral ; and (3) the lagoon basin. There is nothing in the material within the lagoou to favour solution more than in either of the other two regions ; in fact, the platform and bare reef are most exposed to the action because of the small amount of living corals over them. The outside waters take up what they can through the carbonic acid they contain, and supply thereby the wants of the limesecreting polyps, shells, de., and carry on the process of solidification in the débris; the same waters move on over the atoll reef and take up more lime as far as the acid ingredient is present; and then they pass to the lagoon for work similar to that outside, with probably a diminished amount of free carbonic acid, on account of the loss over the reef-ground previously traversed.

The lagoon basin is not, therefore, the part of the atoll that loses most by solution, any more than by abrasion and transX 2 
portation. The outer reefs suffer the most; and yet, if the island is not subsiding at too rapid a rate, they keep extending and encroaching on the ocean, instead of wasting through the drifting into the ocean at large of calcium carbonate in grains and solution; and the shore-platform also preserves its unvaried level notwithstanding the daily sweep of the tidal floods, and the holes that riddle its outer portions.

The remarks, "It is a common observation in atolls that the islets on the reefs are situated close to the lagoon shore;" and such "facts point out the removal of matter which is going on in the lagoons and lagoon channels," * I know nothing to sustain. The width of the shore-platform on the seaward side is always greater than that on the lagoon side; but the outside shore-platform has its width determined by tidal and wave action, and this action is powerful on the ocean side, and feeble on the lagoon side; it produces a high coarse beach on the outside as the inner limit of the platform, and a finer, lower, and much more gently sloping beach on the inside. The amount of erosion is far greater, as it should be, on the side of the powerful agencies.

$f$. The loss to the lagoon by abrasion and solution is reduced to a minimum, in the majority of atolls, by the absence of lagoon entrances, which leaves them with only concealed leakage passages for slow discharge.

Nine tenths of atolls under six miles in length (or in longer diameter), half of those between six and twenty miles, and the majority of all atolls in the Pacific Ocean, have no entrances to the lagoon a fathom deep ; and the larger part of those included in each of these groups have no open entrances at all.

For evidence on this subject, I refer to the Wilkes Expedition Hydrographic Atlas. This Atlas contains maps of nearly sixty coral-islands from the surveys of its officers, drawn on a large scale (one or two miles, rarely four, to the inch).

Out of the number, nine, ranging from $1 \frac{1}{2}$ to 3 English miles in the longer diameter of the reef, have no lagoon, but only a small depression in its place; two of these take in water at high tide, and the rest are dry.

Of those under six miles in length having lagoons, seventeen in number, sixteen are represented as having no entrances to the lagoon at low tide; and the one having an entrance is $5 \times 4$ miles in size. The smallest is about a mile in diameter.

Of those that are six miles or over in length, twenty-nine in number, seventeen have channels and twelve have none.

* Mr. Murray, loc. cit. p. 515. 
Those having channels are mostly over ten miles in length. A list of them is here given with their sizes, and also the proportion of the reef around the lagoon which is under water above third tide, and bare at low tide, a feature of much interest in this connection.

Filitce Group.-Depeyster's : $6 \times 6 \mathrm{~m}$.; three fourths of the encircling reef bare. Ellice's: $9 \times 5 \mathrm{~m}$.; three fourths bare.

Gilbert Group.-Apia: $17 \times 7 \mathrm{~m}$. ; half bare. Tarawa: $21 \times 9 \mathrm{~m}$.; half bare. Taritari: $18 \times 11 \mathrm{~m}$. two thirds bare Apamama: $12 \times 5 \mathrm{~m}$; half bare. Taputenea; west side mostly submerged.

Marshalu Islandos (northern).-Pescadores : $10 \times 8 \mathrm{~m}$.; four fifths bare. Korsakoff: $26 \mathrm{~m}$.; four-fifths bare.

Paumotus.-Peacock; $15 \times 7$ m.; nearly all wooded. Manhii : $13 \times 5 \mathrm{~m}$; nearly all wooded. Raraka : $6 \times 9 \mathrm{~m}$. ; three fourths wooded. Vincennes: $13 \times 9 \mathrm{~m}$.; mostly wooded. Aratica : $18 \times 11 \mathrm{~m}$; ; three fifths bare. Tiokea : $18 \times 4 \mathrm{~m}$.; two thirds wooded. Kruesenstern's : $16 \times 10 \mathrm{~m}$.; mostly wooded. Dean's (or Nairsa): $53 \times 18 \mathrm{~m}$.; half or more bare.

$g$. The absence of open channels in so large a proportion of lagoons, and especially in lagoons of the smaller atolls, appears to be fatal to the abrasion-solution theory. The method of enlarging atolls through currents and solution can act only feebly, if at all, where waters have no free outlet; and this is eminently so with the smaller atolls which have been assumed by the theory to be most favourable in purity of water and in abundant life for progress; if the small cannot grow, the large lagoons cannot be made from them by the proposed method.

Reverse the method, letting the large precede the small (as under the subsidence theory), and then we have a consistent order of events. We have large atoll reefs with several large entrances (like the great barrier-reef about a high island in this and other respects) gradually contracting, and the entrances concurrently narrowing through the growing corals and the consolidating debris, in spite of the efforts of abrasion and solution to keep them open and make them deeper ; and, afterwards, the atoll becoming still smaller until the entrances close up; and, finally, the lagoon-basin is reduced to a dry depression with nothing of the old sea-water remaining except, perhaps, some of its gypsum.

$h$. Instead of small lagoons having the purest waters, the reverse is most decidedly and manifestly the fact, and this 
accords with the reversal in the history just suggested. Since atolls of middle and larger size commonly have one third to two thirds of the encircling reef covered with the sea at onethird tide, making the ocean and lagoon for more than half the time continuous, the large lagoon in such a case has as pure water as the ocean, and commonly as good a supply of food-life, and sometimes as brilliant a display of living corals. But in the smaller atolls, the area of the lagoon has little extent compared with the length and area of the encircling reef; coral-sands and other calcareous material consequently have possession of the larger part of the bottom, and the waters, since they are less pure than those outside, contain fewer and hardier kinds of corals and less life of other kinds. They are exposed, also, to wider variations of temperature than the outer, with injury to many species; and at lowest tides may become destructively overheated by the midday sun, as many a plantation of corals with dead tops for a foot or more bears evidence. In the smallest atolls, the lagoons are liable also to alternations of excessive saltness from evaporation and excessive freshness from rains, and consequently no corals can grow inside, though still flourishing well in the shallow sea about the outer reef. The abore are the facts, not the saggestions of theory.

$i$. We read :- "So great is the destructive and transporting influence of the sea under the combined or antagonistic working of tides, currents, and wind-waves that the whole mass of the reef, as well as the flats and shoals inside, may be said to be in more or less active movement"*. This description of the Tortugas reefs is not applicable to the atolls of the Pacific. Notwithstanding the testimony of Captain Beechey and others about occasional cafastrophes (which are mostly catastrophes to the islets and banks within the lagoons), I was led to look upon a coral-island as one of the most stable of structures. The waves and currents have shaped its reef, shore-platform, and beaches, fitting it well in all respects for its place by means of the forces that were to assail it; and an air of placid repose, as it lies amid the breakers, is its most impressive feature. Through the wind-made and tidal movements the loose sands are drifted along the shores and over the reef; edges of the reef are broken off in gales or by earthquake waves; and occasionally a mushroom islet in the lagoon, where growing corals are not compacted by wave-action, is overthrowu by the same means; but beyond this the structure is singularly defiant of the encroaching waters. 'Earthquakes may bring devastation; and so they may to other lands.

\footnotetext{
* Address, p. 23.
} 


\section{Conclusion.}

With the theory of abrasion and solution incompetent, all the hypotheses of objectors to Darwin's theory are alike weak; for all have made these processes their chief reliance, whether appealing to a calcareous, or volcanic, or mountain-peak basement for the structure. The subsidence which the Darwinian theory requires has not been opposed by the mention of any fact at variance wth it, nor by setting aside Darwin's arguments in its favour; and it has found new support in the facts from the 'Challenger's' soundings off 'Tahiti that had been put in array against it, and strong corroboration in the facts from the West Indies.

Darwin's theory therefore remains as the theory that accounts for the origin of coral reefs and islands.

\section{Central-Pacific Subsidence.}

Darwin, as has been said, took a step beyond direct observation in his inference that the subsidence attested to by each atoll extended over the intermediate seas and characterized a large central area of the ocean. He may be wrong here (and the writer with him), while not wrong in his theory. But, considering the distribution of the Pacific atolls in the ocean, their relation in this respect to the distribution of other Pacific lands, and the facts connected with the history of coral reefs and islands, the generalization appears to be well sustained. The question is here left without further argument, to be considered over the best geographical map of the ocean to be had, and the best bathymetrical map that can be made, only asking that the doubts which physical theory has set afloat may not be allowed by the geologist to warp the judgment or cripple investigation*.

My own agreement with Darwin as to the area of coralreef subsidence was promoted by an early personal study of the oceanic lands. For more than five years previous to passing my third decade I was ranging over the oceans, receiving impressions from a survey of the earth's features. I was

* One point often encountering an à priori doubt is the slowness of the required subsidence. The subsidence over the Appalachian region which preceded the making of the Appalachian Mountains amounted, according to well-ascertained facts (as stated by Hall and Leslie), to at least 30,000 feet. The great trough, nearly a thousand miles long, was in progress through all of Palæozoic time. If the Palæozoic ages covered only $20,000,000$ years (a low estimate) the mean annual rate was $0.018 \mathrm{inch}$, which is less than half a millimetre per year. Such a fact is no evidence as to the rate of the atoll-making subsidence; but, whatever the cause to which the Appalachian subsidence is to be attributed, it is suggestive es to possibilities and probabilities connected with the earth's movements. 
made to see a system of arrangement in the Pacific islands, instead of a "labyrinth ;" to appreciate the vast length of the island-chains in the great ocean with their many parallelisms, and the accordant relations subsisting between them and long lines of atolls. I was thence led to observe the corresponding system in the features of the continental lands, and the more fully so when afterwards it was proved that Geology was not in America merely the study of strata and fossils, but of the successive stages in a growing continent. Thus a conception of the earth as a unit became early implanted, and the idea also of its development as a unit under movements as comprehensive as the system in its feature-lines. My faith in any mountain-making theory hitherto proposed is weak. But that idea of system in structure and progress stands, and, however much ignored by students of the earth's stratigraphy, it must have its explanation in a true theory of the earth's dynamies.

XXX. On an unnoticed Danger in certain Apparatus for Distribution of Electricity. By J. HopKInson, F.R.S.*

WANY plans have been proposed, and several have been I to a greater or less extent practically used, for combining the advantage of economy arising from a high potential in the conductors which convey the electric current from the place where it is generated with the advantages of a low potential at the various points where the electricity is used. A low potential is necessary where the electricity is used; partly because the lamps, whether arc or incandescent, each require a low potential, and partly because a high potential may easily become dangerous to life. Amongst the plans which have been tried for locally transforming a supply of high potential to a lower and safer, the most promising is by the us $\theta$ of secondary generators or induction-coils. It has been proved that this method can be used with great economy of electric power and with convenience; under proper construction of the induction-coils it may also be perfectly safe. It is, however, easy and very natural so to construct them that they shall be good in all other respects but that of safety to life-that they shall introduce an unexpected risk to those using the supply.

In a distribution of electricity by secondary generators, an alternating current is led in succession through the primary coils of a series of induction-coils, one for each group or system of lamps. The lamps connect the two terminals of the

* Communicated by the Author. 